\title{
Federalism and Antitrust Reform
}

\author{
By Herbert Hovenkamp*
}

\begin{abstract}
Ev VER SINCE THE SHERMAN ACT ${ }^{1}$ was passed, the interaction between federal antitrust policy and state lawmaking has been controversial. The framers of the Sherman Act clearly did not intend to displace all state regulation of the economy. ${ }^{2}$ To be sure, under the "dual federalism" that prevailed in the 1890 s, Congress could not have done so. ${ }^{3}$ In that era any attempt to regulate purely intrastate economic affairs would have exceeded congressional power under the Commerce Clause, as the Supreme Court's decision in United States v. E.C. Knight $C o^{4}$ a few years later established. ${ }^{5}$ For their part, the states were empowered at the time to regulate purely intrastate transactions, but not those with a significant interstate impact. ${ }^{6}$ Within this model,
\end{abstract}

* Ben V. \& Dorothy Willie Professor, University of Iowa College of Law.

1. 15 U.S.C. $\$ \S 1-7(2000)$.

2. See Parker v. Brown, 317 U.S. 341, 351 (1943); 1 Phillip E. Areeda \& Herbert Hovenkamp, ANTitrust LaW (3d ed. forthcoming, 2007) (manuscript II 102, 216(a), on file with author); Herbert Hovenkamp, ENTERPRise and AMErican Law, 1836-1937, at 241-95 (1991) [hereinafter HovenKaMP, ENTERPRISE]; James May, The Role of the States in the First Century of the Sherman Act and the Larger Picture of Antitrust, 59 ANTITRust L.J. 93, 100 (1990); James May, Antitrust Practice and Procedure in the Formative Era: The Constitutional and Conceptual Reach of State Antitrust Law, 1880-1918, 135 U. PA. L. REv. 495, 499 (1987); cf. R.E. Spriggs Co. v. Adolph Coors Co., 112 Cal. Rptr. 585, 589 (1974) ("The history of the Sherman Antitrust Act makes it clear that the Congress did not intend that the federal legislation preempt parallel state efforts to control unfair competitive practices.").

3. See Hovenkamp, Enterprise, supra note 2, at 79-92. The classic statements concerning the limitations on state and federal power under the Commerce Clause in the nineteenth century are Felix Frankfurter, The Commerce Clause Under Marshall, Taney AND WaIte, 11-73 (1937); Edward S. Corwin, The Passing of Dual Federalism, 36 VA. L. Rev. 1, 3 (1950). For a good, brief history, see Jenna Bednar \& William N. Eskridge, Jr., Steadying the Court's "Unsteady Path": A Theory of Judicial Enforcement of Federalism, 68 S. CAL. L. REv. 1447,1454 (1995).

4. 156 U.S. 1 (1895).

5. Id. at 17 (holding that the Sherman Act does not reach a sugar trust that manufactured in multiple states when the restraint was not claimed to be in the interstate shipment of sugar).

6. See Wabash, St. Louis \& Pac. Ry. Co. v. Illinois, 118 U.S. 557, 564-65 (1886) (holding that while the state could regulate rates of a completely intrastate rail shipment, it lacked the power to regulate any portion of an interstate shipment, even that part contained entirely within the state); HoVENKAMP, ENTERPRISE, supra note 2, at 79-83. 
there were very few perceived overlaps, ${ }^{7}$ and Congress really had no choice but to recognize the power of the states to engage in economic regulation within their own boundaries.

Nevertheless, even within this regime, conflicts could arise. Already in 1904 the Supreme Court had to face a "state action" defense to a government antitrust challenge. The Northern Securities Company had taken advantage of a provision of the New Jersey Corporation Act, which permitted the creation of a holding company that held out-of-state assets. ${ }^{8}$ The result was a merger of the two most significant east-west interstate railroads in the northern part of the United States. The defendants argued that the Sherman Act was not intended to preempt state law. ${ }^{9}$ Because the merger in question was justified by state corporation laws, it could not violate the antitrust laws. ${ }^{10}$ However, the Sherman Act permitted the government to pursue "combinations" in restraint of trade, making no distinction between purely private combinations ${ }^{11}$ and those that were formed with the sanction of a state government. ${ }^{12}$ The Supreme Court rejected this "state action" defense in only a few sentences, concluding that while the New Jersey statute permitted holding companies, there was no evidence that it was intended to permit anticompetitive combinations. ${ }^{13}$ The Court also added that "[i]t cannot be said that any state may give a corporation ... authority to restrain interstate ... commerce against the will of ... Congress." 14

The antitrust "state action" 15 doctrine in its modern form was made necessary by the collapse of dual federalism in the $1940 \mathrm{~s}$, partic-

7. HovenKamp, ENTERPRISE, supra note 2, at 79-92.

8. N. Sec. Co. v. United States, 193 U.S. 197, 326-27 (1904).

9. Id. at $333-34$.

10. Id. at 371.

11. E.g., United States v. Trans-Mo. Freight Ass'n, 166 U.S. 290, 341 (1897) (condemning privately created joint venture among railroads under Sherman Act); United States v. Joint-Traffic Ass'n, 171 U.S. 505, 577 (1898). Both Trans-Missouri and Joint-Traffic involved "joint running arrangements," which were joint ventures that did not require the formation of a new corporation or the sanction of state corporate law. Trans-Mo., 166 U.S. at 365 .

12. N. Sec., 193 U.S. at $345-46$.

13. Id.

14. Id. at 346.

15. The antitrust "state action" doctrine is different from and much narrower than the Fourteenth Amendment state action doctrine, and the two are rarely confused. The Fourteenth Amendment doctrine automatically extends to all states and government subdivisions, as well as their officials acting under color of state law and occasionally even private entities performing public functions. In contrast, the antitrust state action immunity applies only where the requirements of clear articulation and active supervision of 
ularly with the Supreme Court's decision in Wickard v. Filburn, ${ }^{16}$ which expanded federal economic power to reach predominately intrastate transactions provided that they "affected" United States commerce. ${ }^{17}$ At that point, significant conflict between federal antitrust and state regulation became possible. The Supreme Court responded a year later with Parker $v$. Brown, ${ }^{18}$ which created the antitrust state action doctrine, immunizing a state-sanctioned agreement that reduced the output of California raisins. ${ }^{19}$

While the state action doctrine was entirely a creation of the Supreme Court, the views of Congress during this period were largely sympathetic. In United States $v$. South Eastern Underwriters, ${ }^{20}$ decided two years after Wickard and a year after Parker, the Supreme Court held that insurance transactions were within interstate commerce and thus within the reach of the Sherman Act. ${ }^{21}$ Congress then responded in 1945 with the McCarran-Ferguson Act, ${ }^{22}$ which immunized the "business of insurance" from most federal legislation, including the antitrust laws. ${ }^{23}$ McCarran-Ferguson is significant in part because in 1945, when that statute was passed, Congress clearly did have the power to reach intrastate transactions with interstate effects, thus overriding inconsistent state mandates. ${ }^{24}$ However, Congress largely chose not to do so with respect to insurance, preferring at that time to leave most of its regulation to the states. ${ }^{25}$

Thus, in the space of four years in the early 1940s, the Supreme Court and Congress established what has become the modern framework for understanding the relationship between federal antitrust policy and regulation by the states. The question today is whether this

private conduct have been met. All further references to "state action" in this Article are to the antitrust doctrine.

16. 317 U.S. 111 (1942).

17. Id. at $121,124$.

18. 317 U.S. 341 (1943).

19. Id. at 368 .

20. 322 U.S. 533 (1944).

21. Id. at 540-42. The decision substantially overruled the Court's decision in Paul $v$. Virginia, 75 U.S. 168, 183 (1868), that insurance had an essentially intrastate character. In Paul, the Court concluded that a Virginia statute requiring out of state insurance companies to obtain a license before doing business in Virginia did not offend either the Privileges and Immunities Clause or the Commerce Clause. 75 U.S. at 177-83.

22. Ch. 20, 59 Stat. 33 (1945) (current version at 15 U.S.C. $\$ \$ 1011-1012$ (2000)); Ch. 326, 61 Stat. 448 (1947) (current version at 15 U.S.C. $\$ \S 1011-1015$ (2000)).

23. Ch. 20, 59 Stat. 33; Ch. 326, 61 Stat. 448.

24. Wickard v. Filburn, 317 U.S. 111, 128-29 (1942).

25. Baddia J. Rashid, Note, The Trend of Insurance Regulation, 35 GEo. L.J. 102, 102-03 (1946). 
framework still works, and if it does not, whether it needs to be modernized or jettisoned completely. This Article offers a few basic considerations and some suggestions for reform.

\section{Considerations Used in Evaluating the Modern Relationship Between Federal Antitrust Policy and States Regulation}

\section{A. Changing Attitudes Toward Regulation and the Role of Antitrust}

The relationship between federal antitrust policy and state economic regulation is driven in part by attitudes toward regulation. Although the point is easily overstated, today we are less optimistic about regulation than we were a half century ago. The state action exemption was formulated at a time when federal power was expanding rapidly and confidence in regulation was generally high. ${ }^{26}$ By contrast, in the last quarter century we have become much less confident in regulation at every government level. The rise of public choice theory and the deregulation movement reflect different aspects of these changes. ${ }^{27}$ Just as these changes have occasioned less deference to federal regulation, they can do the same thing for state or local government regulation.

One is tempted to say that during this same period we have acquired more confidence about the role of antitrust enforcement, as an alternative to affirmative regulation, in producing efficient economic outcomes. But that point is open to dispute, and some critics take just as dim a view of antitrust enforcement as they do of regulation. ${ }^{28}$ To be sure, deregulation has increased the domain of antitrust by removing regulatory immunities that once existed. ${ }^{29}$ As a result, antitrust is now applied in markets such as air passenger travel or telecommunications where there was once thought to be a substantial regulatory immunity. To say that antitrust's domain has expanded,

26. For historical perspective, see 1A AREEDA \& HovenkAMP, supra note 2, I 241.

27. See 1A id. I $241 \mathrm{~b} 2$ (public choice); $1 \mathrm{~A}$ id. I $241 \mathrm{b3}$ (changes in economic theory arguing for deregulation). See generally Daniel A. Farber \& Philip P. Fruckey, Law and Public Choice: A Critical Introduction (1991). For specific application to regulation, see Richard A. Posner, Theories of Economic Regulation, 5 Bell J. Econ. \& MGMT. SCI. 335 (1974); George J. Stigler, The Theory of Economic Regulation, 2 BeLl J. ECON. \& MGMT. SCI. 3 (1971).

28. E.g., Frank H. Easterbrook, The Limits of Antitrust, 63 TEx. L. REv. 1, 15 (1984); Frank H. Easterbrook, Foreword: The Court and the Economic System, 98 HARv. L. Rev. 4, 16 (1984).

29. See 1A Areeda \& Hovenkamp, supra note 2, I 241. 
however, is not necessarily to say that our confidence level in antitrust enforcement has increased as confidence in regulation has declined. One might as easily say that our confidence level in all types of government intervention in the market has declined, and that the decline cuts across both regulatory and antitrust policy.

Actually, the antitrust story is more nuanced than this. While we have become far more skeptical about our once aggressive policies against exclusionary practices, such as vertical restraints and mergers, antitrust policy is as fierce as ever about naked cartels. Problematically, however, the types of restraints for which state law regulatory immunity is sought run the full gamut. Some state regulation condones fairly blatant collusion. ${ }^{30}$ However, antitrust challenges to state action are frequently brought under the weakest possible antitrust theories. ${ }^{31}$ For example, it is hard to see any antitrust violation in a city's order to the dominant cable company to restrain its expansion for a time so that the city might assess whether entry by rivals is appropriate; ${ }^{32}$ or a municipality's refusal to supply utilities to outlying areas that had not been annexed; 33 or its decision to create its own cable television system rather than purchasing CATV services from a private firm. ${ }^{34}$ Many other state action cases involve challenges to such things as exclusive contracts, ordinarily treated as either exclusive dealing or tying. The great majority of such arrangements are lawful even when the firm imposing the arrangement is a monopolist, and in many of these cases the hospital or similar publicly operated institution claim-

30. E.g., FTC v. Ticor Title Ins. Co., 504 U.S. 621 (1992) (noting weak state supervision of title insurance rate bureaus, leading effectively to unsupervised collusion); New Eng. Motor Rate Bureau, Inc. v. FTC, 908 F.2d 1064, 1071 (1st Cir. 1990) (similar facts); In $r e$ New Eng. Motor Rate Bureau, Inc., 112 F.T.C. 200 (1989) (vacated on other grounds); Mass. Bd. of Registration of Optometry, 5 Trade Reg. Rep. (CCH) I 22,555 (1988); see 1A Areeda \& Hovenkamp, supra note 2, I $226 \mathrm{c}$.

31. See 1 AReEda \& Hovenkamp, supra note 2, I 228b.

32. Cmty. Commc'n Co., Inc. v. City of Boulder, 455 U.S. 40, 44-45 (1982). The municipal ordinance challenged as an antitrust violation delayed the territorial expansion of the plaintiff, the dominant incumbent cable firm, while the city council decided whether to open the field to additional competitors. In all events, a dominant firm alleging that a restraint limited its power to expand its monopoly so that new rivals could be given an opportunity to come in is not a victim of antitrust injury. See Brunswick Corp. v. Pueblo Bowl-O-Mat, Inc., 429 U.S. 477, 489 (1977); 2 AREeda \& Hovenkamp, supra note 2, II 337 (2d ed. 2000).

33. Town of Hallie v. City of Eau Claire, 471 U.S. 34, 37 (1985). Placed in a private context, the claim in Hallie was tantamount to claiming that General Motors violated the antitrust laws by providing snow removal services only to its own properties, but not to adjoining properties that it did not own.

34. Paragould Cablevision, Inc. v. City of Paragould, 930 F.2d 1310 (4th Cir. 1991), cert. denied, 502 U.S. 963 (1992). 
ing the exemption was only one of many competitors. ${ }^{35}$ Still others are challenges to such practices as peer review, which are rarely anticompetitive unless abused. ${ }^{36}$ Others involve standard setting or rule making that cannot be an antitrust violation because no benefit accrues to the organization making the rules. ${ }^{37}$

Some see the rise of public choice theory as a compelling reason for either narrowing the reach of the state action immunity or for removing the immunity for proven instances of regulatory capture. ${ }^{38}$ However, it is not clear to me that antitrust tribunals need to respond in any programmatic way to changes in regulatory attitude. Repairing imperfections in political processes is not antitrust's purpose. Neither Congress nor the Supreme Court has ever authorized the use of antitrust as a wide ranging mandate to fix imperfections in government process. Rather, the antitrust laws are explicitly designed to control private restraints. Further, most serious abuses of government process are better remedied by laws that are more directly tailored for that purpose, such as those condemning bribery, financial abuses, or other forms of corruption. These laws do not carry antitrust's additional, significant proof requirements of market power and economic harm, and at least some of them are enforceable by criminal sanctions.

Public choice is relevant in another sense, however. Public choice theory serves as a warning that many so-called "public" restraints are really private restraints by another name. That message is twofold: if a state or local government really authorizes and effectively supervises a private restraint, so be it. Federal antitrust cannot intervene simply because federal tribunals believe that the regulation in question is illadvised, inefficient, or a manifestation of interest group capture. How-

35. See, e.g., Jackson, Tenn. Hosp. Co. v. W. Tenn. Healthcare, Inc., 414 F.3d 608, 611 (6th Cir. 2005); Bolt v. Halifax Hosp. Med. Ctr., 891 F.2d 810, 824 (11th Cir.), cert. denied, 495 U.S. 924 (1990).

36. See, e.g., Bolt v. Halifax Hosp. Med. Ctr., 980 F.2d 1381, 1388 (11th Cir. 1993).

37. Earles v. State Bd. of Certified Pub. Accountants of La., 139 F.3d 1033, 1043 (5th Cir.), cert. denied, 525 U.S. 982 (1998) (state accountancy board promulgates rule prohibiting CPAs, its own members, from selling securities).

38. E.g., John T. Delacourt \& Todd Zywicki, The FTC and State Action: Evolving Views on the Proper Role of Government, 72 ANTITRust L.J. 1075 (2005). Other good discussions include Robert P. Inman \& Daniel L. Rubinfeld, Making Sense of the Antitrust State-Action Doctrine: Balancing Political Participation and Economic Efficiency in Regulatory Federalism, 75 TEx. L. REV. 1203 (1997); Thomas M. Jorde, Antitrust and the New State Action Doctrine: A Return to Deferential Economic Federalism, 75 CAL. L. Rev. 227 (1987); William H. Page, Interest Groups, Antitrust, and State Regulation: Parker v. Brown in the Economic Theory of Legislation, 1987 Duke L.J. 618 (1987); William H. Page \& John E. Lopatka, State Regulation in the Shadow of Antitrust: FTC v. Ticor Title Insurance Co., 3 Sup. CT. ECON. Rev. 189 (1993); John Shephard Wiley, Jr., A Capture Theory of Antitrust Federalism, 99 HaRv. L. REv. 713 (1986). 
ever, antitrust need not countenance restraints in which the effective decision makers are the market participants themselves. ${ }^{39}$

\section{B. Concerns for Federalism}

Pulling in the opposite direction, the trimming of the federal regulatory agenda has been accompanied by a return to federalism-i.e., to take preemptive regulatory power away from the federal government and restore it to the states. This would seem to suggest more deference by federal antitrust tribunals to state regulation, and thus an expanded role for state action immunity.

Concerns for federalism were not particularly prominent in the Supreme Court's Parker decision. Rather, the Court seemed to regard the regulation in question as enacted in the public interest. ${ }^{40}$ In sharp contrast, the first edition of the Areeda \& Turner ANTITRUST LAW treatise, published in 1978, seated the state action doctrine squarely within the authors' concerns for federalism. Areeda and Turner argued that the "proper" grounds for state action immunity were twofold. First, there should not be Parker immunity "without adequate public supervision" of private conduct. ${ }^{41}$ Second, there must be "authorized state action clearly intended to displace antitrust law." ${ }^{2}$ The Supreme Court picked up these criteria almost verbatim in its Midcal decision three years later, ${ }^{43}$ and since then, clear authorization and active supervision have come to define the two elements for the state

39. See discussion infra notes $81-86$.

40. See Parker v. Brown, 317 U.S. 341, 351-52 (1943). On this point, see Delacourt \& Zywicki, supra note 38.

41. 1 Phillip Areeda \& Donald F. Turner, Antitrust Law II 213 (1978). The title of this Paragraph was "Proper Immunity Limits I: No Parker Immunity Without Adequate Public Supervision," and Areeda and Turner state:

[A] state may be free to determine for itself how much competition is desirable, provided that it substitutes adequate public control wherever it has substantially weakened competition .... [T] he adequate supervision criterion ensures that state-federal conflict will be avoided in those area in which the state has demonstrated its commitment to a program through its exercise of regulatory oversight. At the same time, it guarantees that when the Sherman Act is set aside, private firms are not left to their own devices. Rather, immunity will be granted only when the state has substituted its own supervision for the economic constraints of the competitive market.

1 Id. at 72-73 (footnotes omitted).

42. See 1 id. I 214, which was titled "Proper Immunity Limits II: No Parker Immunity Without Authorized State Action Clearly Intended to Displace Antitrust Law."

43. Cal. Retail Liquor Dealers Ass'n v. Midcal Aluminum, Inc., 445 U.S. 97, 106 (1980). 
action doctrine, at least when the conduct in question is that of private parties. ${ }^{44}$

Thus, it seems clear that, while the initial Parker $v$. Brown state action doctrine rested on ideas about regulatory supremacy rather than federalism, today that is no longer the case. Since Midcal, neither the Supreme Court nor the lower courts have indulged any presumption that state regulation is in the "public interest," or that it produces better outcomes than antitrust laws. Rather, the foundation of the doctrine lies in discernment of the state's own commitment to regulate. If that commitment is appropriately stated, then the federal tribunal should not intervene no matter what it may think of the merits of the regulation at issue.

\section{Growth of Multistate Markets: Spillovers}

The enlargement of markets and internationalization of the economy that provided the backdrop for the expansion of federal regulatory power in the 1930s and 1940s has not subsided. To the contrary, the rise of electronic markets has only served to accelerate the pace at which markets have become at least national and often international or even global. ${ }^{45}$ As a general proposition, regulation of large markets by small governments is inefficient because it results in excessive self dealing and protectionism. ${ }^{46}$

\section{Applications: McCarran-Ferguson and "State Action"}

\section{A. McCarran-Ferguson Insurance Immunity: The Case for Repeal}

When the McCarran-Ferguson Act was passed in 1945, state regulation of insurance was significant, extending to such things as rates, coverage, and financial integrity. ${ }^{47}$ The South Eastern Underwriters

44. Id. See 1 Areeda \& Hovenkamp, supra note 2, I $221 \mathrm{f}$ (3d ed.). Under the postMidcal case law the conduct of private parties must be both authorized and supervised. The conduct of the "state itself" is inherently authorized and need not be supervised. Id. The conduct of officials representing state subdivisions, such as municipalities or most agencies, must be authorized but need not be supervised. For elaboration, see generally 1 id. II 221-27.

45. Herbert Hovenkamp \& John A. Mackerron III, Municipal Regulation and Federal Antitrust Policy, 32 UCLA L. REv. 719, 720 (1985).

46. Id.

47. See Robert H. JerRy, Understanding Insurance Law \$ 21, at 74-75 (2d ed. 1996) (noting that, by 1919, thirty-six states had "departments" or commissions charged with regulating insurance, and that by 1930 these agencies had been given authority to collect information from insurers and to review at least some business decisions and approve some forms); see also John G. Day, Dept. of Transp., Economic Regulation of Insurance in the UNITED STATES 18 (1970) (stating that by 1944 there was substantial state agency involve- 
case $^{48}$ threatened to undermine state regulation by permitting federal antitrust to be inserted into a market that had traditionally been reserved for the states. The first paragraph of Justice Black's opinion for the Court defined the issue:

For seventy-five years this Court has held, whenever the question has been presented, that the Commerce Clause of the Constitution does not deprive the individual states of power to regulate and tax specific activities of foreign insurance companies which sell policies within their territories. Each state has been held to have this power even though negotiation and execution of the companies' policy contracts involved communications of information and movements of persons, moneys, and papers across state lines. Not one of all these cases, however, has involved an Act of Congress which required the Court to decide the issue of whether the Commerce Clause grants to Congress the power to regulate insurance transactions stretching across state lines. Today for the first time in the history of the Court that issue is squarely presented and must be decided. ${ }^{49}$

The South Eastern Underwriters case itself involved allegations of price-fixing among a half dozen insurers serving several states, as well as an agreement to boycott rivals and force purchasers to deal only with the defendants. ${ }^{50}$ The McCarran-Ferguson Act would have immunized the first of these claims, provided that insurance was adequately regulated, but its "boycott" exception would probably have denied immunity to the second. ${ }^{51}$

Notwithstanding its then recent decision in Parker, the South Easterm Underwriters opinion took a much less accommodating attitude toward state regulation:

$[\mathrm{I}] \mathrm{t}$ is argued at great length that virtually all the states regulate the insurance business on the theory that competition in the field of insurance is detrimental both to the insurers and the insured, and that if the Sherman Act be held applicable to insurance much of this state regulation will be destroyed. The first part of this argu-

ment in the process of insurance rate regulation). On specific instances of state regulation, see, for example, Am. Druggists' Fire Ins. Co. of Cincinnati, Ohio v. State Ins. Bd., 84 P.2d 614, 616 (Okla. 1938); see also Hassler v. Engberg, 48 N.W.2d 343, 347-48 (Minn. 1951); English Freight Co. v. Knox, 180 S.W.2d 633 (Tex. Civ. App. 1944); Caminetti v. Manierre, 142 P.2d 741 (Cal. 1943); United Employers Cas. Co. v. Pearlman Auto Parts \& Supply Co., 173 S.W.2d 374, 375 (Tex. Civ. App. 1943).

48. United States v. S. E. Underwriters Ass'n, 322 U.S. 533 (1944).

49. Id. at 534 .

50. Id. at 535 .

51. The Act contains an exception for boycotts. See 15 U.S.C. $\S 1013(b)$ (2000) ("Nothing contained in this chapter shall render the ... Sherman Act inapplicable to any agreement to boycott, coerce, or intimidate, or act of boycott, coercion, or intimidation."); 1 AREeda \& Hovenkamp, supra note 2, I 220 (3d ed.). 
ment is buttressed by opinions expressed by various persons that unrestricted competition in insurance results in financial chaos and public injury. Whether competition is a good thing for the insurance business is not for us to consider. Having power to enact the Sherman Act, Congress did so; if exceptions are to be written into the Act, they must come from the Congress, not this Court.

The argument that the Sherman Act necessarily invalidates many state laws regulating insurance we regard as exaggerated. Few states go so far as to permit private insurance companies, without state supervision, to agree upon and fix uniform insurance rates. . . . No states authorize combinations of insurance companies to coerce, intimidate, and boycott competitors and consumers in the manner here alleged, and it cannot be that any companies have acquired a vested right to engage in such $\ldots . .52$

Congress then responded with the McCarran-Ferguson Act, which was intended to restore the state regulatory prerogative. The Act exempted the insurance industry from federal laws of general application and included an antitrust exemption that applied if the insurance business was regulated by state law. 53

In 1945, when the McCarran-Ferguson Act was passed, Congress apparently did not foresee subsequent developments in the antitrust state action doctrine that would have served to immunize many insurance restraints, provided that they were adequately regulated. Indeed, the state action doctrine would have provided a much more balanced approach to the problem of ineffectual state insurance regulation.

One of the ironies of the McCarran-Ferguson Act is that it tends to immunize practices that pose a significant threat to competition, such as competitor agreements fixing rates or reducing policy coverage, ${ }^{54}$ but not various vertical practices that are almost certainly not antitrust violations at all. By its terms, the statute applies only to the "business of insurance," which involves such things as the making of

52. S. E. Underwriters, 322 U.S. at 561-62 (emphasis added) (citing Parker as an example of a situation where the state did authorize such combinations).

53. 15 U.S.C. $\$ 1012(b)$. The Act provides:

No Act of Congress shall be construed to invalidate, impair, or supersede any law enacted by any State for the purpose of regulating the business of insurance, or which imposes a fee or tax upon such business, unless such Act specifically relates to the business of insurance: Provided, That ... [the antitrust laws and FTC Act] shall be applicable to the business of insurance to the extent that such business is Id. not regulated by State Law.

54. See, e.g., Gilchrist v. State Farm Mut. Auto. Ins. Co., 390 F.3d 1327 (11th Cir. 2004) (immunizing agreement among insurers to require use of inferior replacement crash parts in auto repair). 
rates or the determination of policy coverage. ${ }^{55}$ On the other hand, purely vertical arrangements under which insurers provide prescription drugs or other non-insurance services or engage in peer review of providers are frequently held to fall outside the "business of insurance," and thus are non-immune. ${ }^{56}$ The same is true of insurer efforts at cost control via limitations of such things as auto repair prices. ${ }^{57}$ In sum, the statute tends to immunize serious horizontal restraints, while finding no immunity for vertical restraints that are far less likely to be anticompetitive.

While the statute seems to allow for broader application of the antitrust laws to insurance than other federal provisions, ${ }^{58}$ the courts have not read it that way. Further, the phrase "regulated by state law" in the McCarran-Ferguson Act has come to mean something quite different than the "authorization" and "active supervision" required by the state action doctrine. To illustrate, suppose that the state has insurance regulation in place, but the general thrust of this regulation is to oppose horizontal agreements fixing insurance premiums. In such a case, one might say that a Sherman Act complaint alleging unlawful price fixing would be in furtherance of, rather than inconsistent with, the state's regulatory policy. Nevertheless, the courts generally agree that the Sherman Act complaint is preempted. The mere presence of state regulation is sufficient to oust the federal antitrust claim.

In addition, the courts have generally been satisfied with virtually any degree of regulation, and even the most superficial indicators of supervision. ${ }^{59}$ They have suggested that the mere existence of an

55. 15 U.S.C. $\$ 1011$.

56. Id.

57. See Union Labor Life Ins. Co. v. Pireno, 458 U.S. 119, 134 (1982) (holding that peer review is not immune); Group Life \& Health Ins. Co. v. Royal Drug Co., 440 U.S. 205, 232-33 (1979) (holding that there is no immunity for health insurer's agreement with pharmacies setting maximum rates for prescriptions for its insureds); see also Brillhart v. Mut. Med. Ins., Inc., 768 F.2d 196, 200 n.3 (7th Cir. 1985) (holding that physician's agreement to provide medical services to subscribers at price to be determined by insurance company is not immune); St. Bernard Hosp. v. Hosp. Serv. Ass'n, 618 F.2d 1140 (5th Cir. 1980) (holding that contract limiting reimbursement of plaintiff for-profit hospital to average charges of non-profit hospitals is not immune); Liberty Glass Co. v. Allstate Ins. Co., 607 F.2d 135, 136 (5th Cir. 1979) (holding that insurer's cost-control arrangements involving other repairers is not immune).

58. The debates indicate that Congress intended to leave more room for antitrust enforcement against the insurance industry than for the application of other laws not explicitly directed at the insurance industry. See, e.g., 91 CoNG. REc. 1444 (1945) (remarks of Sen. Pepper); id. at 1484 (remarks of Sen. Murdock).

59. See Crawford v. Am. Title Ins. Co., 518 F.2d 217, 220 (5th Cir. 1975) (stating that an Alabama statute prohibiting "all unfair methods of competition" was sufficient regulation to create McCarran immunity); Oh. AFL-CIO v. Ins. Rating Bd., 451 F.2d 1178, 1184 
agency or official with insurance oversight is adequate regulation. ${ }^{60}$ The Ninth Circuit believes that the mere fact that the state has appointed an insurance commissioner and required him to approve all policies is sufficient. ${ }^{61}$ In another case, it inferred sufficient regulation from the fact that a state statute banned unfair or deceptive practices in the health insurance industry. ${ }^{62}$ The courts have not required authorization of the specific conduct that is the subject of the antitrust challenge. ${ }^{63}$ The Eighth Circuit has held that a statute giving the state power to "investigate" rates and methods of competition was sufficient regulation to support the immunity, even if there was no evidence that actual investigating was occurring. ${ }^{64}$

In sum, the McCarran-Ferguson immunity requires no "active supervision" of private conduct at all, and only the most general statement of authorization, certainly nothing like the authorization requirement in the state action doctrine.

While principles of federalism may require that federal antitrust authority yield on matters where a state has made clear its wish to regulate, no principle mandates such yielding to little more than na-

(6th Cir. 1971), cert. denied, 409 U.S. 917 (1972) (“[T]here is nothing in the language of the McCarran Act or in its legislative history to support the thesis that the Act does not apply when the state's scheme of regulation has not been effectively enforced."); see also Gilchrist, 390 F.3d at 1334 (finding immunity for alleged insurer agreement reducing quality of repair parts; noting that Florida, the most relevant state, regulated the general industry intensely, and that many states also regulate the use of non-OEM repair parts).

60. For example, FTC v. National Casualty, 357 U.S. 560, 564-65 (1958), refused to inquire into how state regulatory provisions were applied, with the possible exception where the regulation was a "mere pretense." Accord Ocean State Physicians Health Plan, Inc. v. Blue Cross \& Blue Shield of R.I., 883 F.2d 1101, 1108-09 (1st Cir. 1989), cert. denied, 494 U.S. 1027 (1990); In re Workers' Comp. Ins. Antitrust Litig., 867 F.2d 1552, 1557-58 (8th Cir.), cert. denied, 492 U.S. 920 (1989); Health Care Equalization Comm. v. Iowa Med. Soc'y, 851 F.2d 1020, 1029 (8th Cir. 1988).

61. Freier v. N.Y. Life Ins. Co., 679 F.2d 780, 782 (9th Cir. 1982); see also Proctor v. State Farm Mut. Auto. Ins. Co., 675 F.2d 308, 317 (D.C. Cir.), cert. denied, 459 U.S. 839 (1982) (declining to disturb district court finding that virtually any regulation specifically mentioning insurance industry will suffice).

62. Klamath-Lake Pharm. Ass'n v. Klamath Med. Serv. Bureau, 701 F.2d 1276, 1287 (9th Cir.), cert. denied, 464 U.S. 822 (1983).

63. See, e.g., Addrisi v. Equitable Life Assurance Soc'y of the United States, 503 F.2d 725, 728 (9th Cir. 1974), cert. denied, 420 U.S. 929 (1975) (finding that a simple statute regulating unfair practices in insurance industry sufficient, regardless of "whether the ... laws proscribe or permit the alleged acts of economic coercion in the issuance of life insurance policies" challenged in this case).

64. Workers Comp. Ins., 867 F.2d at 1558. A concurring judge objected: "Given Minnesota's intentional deregulation of workers' compensation rates, I would find that Minnesota does not 'regulate' these rates for purposes of . . McCarran-Ferguson. While the state did maintain a general regulatory presence in the field, there was no specific regulation targeted at the alleged practices at issue ... ." Id. at 1569 (Beam, J., concurring). 
ked private power. One can protest, of course, that today many states regulate their insurance markets vigorously and are constantly on the lookout for abuses. But in those situations repeal would not be harmful, for the state action immunity would protect the results.

Furthermore, the idea expressed by the Supreme Court in Paulv. Virginia $^{65}$ that insurance is largely a matter of state contract law is not close to the reality we live in today. ${ }^{66}$ Insurance is very largely sold in multistate or even national markets. While this fact may not make state regulation unimportant, it exacerbates the possibility of socially harmful spillovers.

In sum, repeal of the McCarran-Ferguson Act need not have any harmful consequences for federalism or the competitive health of the insurance industry. Bona fide regulatory oversight will continue to qualify the industry for the state action exemption, provided that the authorization and supervision requirements are met.

\section{B. Reform of the Antitrust "State Action" Doctrine}

The current Parker state action immunity doctrine could be improved in several ways. First, courts can apply the articulation requirement more narrowly. Second, the FTC's suggestion of requiring state regulatory agencies to provide reasoned elaborations in order to meet

65. 75 U.S. 168, 183 (1868); see discussion supra note 21.

66. Indeed, the interstate character of the insurance industry was already clear in the 1940s, when South Eastern Underwriters was decided. In his opinion for the Court, Justice Black described it this way:

This business is not separated into 48 distinct territorial compartments which function in isolation from each other. Interrelationship, interdependence, and integration of activities in all the states in which they operate are practical aspects of the insurance companies' methods of doing business. A large share of the insurance business is concentrated in a comparatively few companies located, for the most part, in the financial centers of the East. Premiums collected from policyholders in every part of the United States flow into these companies for investment. As policies become payable, checks and drafts flow back to the many states where the policyholders reside. The result is a continuous and indivisible stream of intercourse among the states composed of collections of premiums, payments of policy obligations, and the countless documents and communications which are essential to the negotiation and execution of policy contracts. Individual policyholders living in many different states who own policies in a single company have their separate interests blended in one assembled fund of assets upon which all are equally dependent for payment of their policies. The decisions which that company makes at its home office-the risks it insures, the premiums it charges, the investments it makes, the losses it pays-concern not just the people of the state where the home office happens to be located. They concern people living far beyond the boundaries of that state.

United States v. S.E. Underwriters Ass'n, 322 U.S. 533, 541-42 (1944) (footnote omitted). 
the active supervision requirement has merit. Third, courts must develop a coherent doctrine with which to address spillovers. Fourth, administrative problems in the disposition of antitrust cases must be remedied. Finally, antitrust tribunals must be more sensitive to substantive issues of antitrust policy.

\section{Articulation Requirement Reforms}

First, too many courts interpret the authorization requirement far too broadly. In Midcal, the Supreme Court required clear articulation and affirmative expression of a state's intent to authorize the challenged restraint. ${ }^{67}$ Writing a few years prior to Midcal, Areeda and Turner expressed this requirement as a "clear statement" rule that presumed lack of immunity unless the relevant statute stated its intent clearly. 68

After a few years of restrictive interpretations of this requirement, the Supreme Court loosened it up, finding in Town of Hallie $v$. City of Eau Claire 59 that it was sufficient if the restraint was a "foreseeable result" of the regulatory authorization. ${ }^{70}$ Since Hallie, the trend in the lower courts has been to interpret state statutes generously so as to find authorization. ${ }^{71}$ Indeed, the courts have gone so far as to infer clear articulation from such things as the granting of ordinary corporate powers-inferring, for example, that a general grant of the cor-

67. Cal. Retail Liquor Dealers Ass'n v. Midcal Aluminum, 445 U.S. 97, 105 (1980).

68. See 1 AREEDA \& TURNer, supra note 41, I 221:

Both the meaning of state approval and the extent of state authorization must be subject to a clear statement requirement. Adoption of a policy requiring a state to make a clear statement of its intention to supplant competition reconciles the interests of the states in adopting noncompetitive policies with the strong national policy favoring competition, and is consistent with the canon of federal statutory construction that exemptions to the antitrust laws are not to be lightly inferred. Where there is no other indication of the proper scope of an officer's authority or of the meaning of state approval, a clear statement requirement is the best approach, because it ensures that the strong federal policy embodied in the antitrust laws will not be set aside where not intended by the state, and yet also guarantees that the state will not be prevented by the antitrust laws alone from supplanting those laws as long as it makes its purpose clear.

The clear statement requirement does not prevent the state from indicating its interest, as it can always make its intent clear. It merely ensures that the inertia in the system is used in the service of the federal interest in free competition.

1 Id. (footnotes omitted).

69. 471 U.S. 34 (1985).

70. Id. at 42; accord City of Columbia v. Omni Outdoor Adver., Inc., 499 U.S. 365; 373 (1991).

71. See 1 Areeda \& Hovenkamp, supra note 2, 11 224-25 (3d ed.). 
porate power to make contracts authorized a public hospital's anticompetitive exclusionary contracts. ${ }^{72}$

Other decisions have properly been much more restrictive. One court very wisely rejected the argument that courts should infer:

a policy to displace competition from naked grants of authority. These are the enabling statutes by which myriad instruments of local government across the country gain basic corporate powers. To infer a policy to displace competition from, for example, authority to enter into joint ventures or other business forms would stand federalism on its head. A state would henceforth be required to disclaim affirmatively antitrust immunity, at the peril of creating an instrument of local government with power the state did not intend to grant. The immediate practical effect would be the extension of the Parker principle downward, contrary to the teaching that local instruments of government are subject to the Sherman Act. ${ }^{73}$

Although Hallie permitted an inference of authorization to be drawn from foreseeability, the inference that the Supreme Court drew in that case was not a particularly long stretch. The City of Eau Claire was accused of refusing to provide sewage treatment services to unincorporated areas around it unless these areas first agreed to be incorporated. ${ }^{74}$ The authorizing provision that the City relied on expressly permitted the City to refuse to provide services to unincorporated ar-

72. See Martin v. Mem'l Hosp. at Gulfport, 86 F.3d 1391 (5th Cir. 1996) (municipal hospital's exclusive contract with physician to supervise kidney disease center was foreseeable consequence of state statute authorizing such hospitals to contract for the provision of services, including entering management contracts, but not explicitly stating that such contracts could be exclusive); Jackson, Tenn. Hosp. Co., v. W. Tenn. Healthcare, Inc., 414 F.3d 608 (6th Cir. 2005) (authority to enter into contracts with physicians implied authority to enter into anticompetitive agreements); see also Recombinant DNA Tech. \& Patent Contract Litig., 874 F. Supp. 904, 911 n.73 (S.D. Ind. 1994) (holding that a statute authorizing a university to "acquire by grant, purchase, gift, devise, lease, or by the exercise of the right of eminent domain, and . . . hold use, sell, lease, or dispose of any real or personal property necessary for the full exercise or convenient or useful for the carrying on of any of its powers ...." authorized it to agree with a private firm to obtain an exclusive patent license by fraud). No doubt the court was impelled by serious doubts of any antitrust violation; but if there were one, a statute giving a university a general power to acquire, manage, and dispose of property hardly includes anticompetitive agreements in violation of federal antitrust law as a foreseeable consequence.

73. Surgical Care Ctr. of Hammond v. Hosp. Serv. Dist., 171 F.3d 231, 236 (5th Cir.), cert. denied, 528 U.S. 964 (1999). The court refused to find authorization from legislation that gave a hospital the power to contract and to enter into joint ventures with other health providers. As it noted, "Not all joint ventures are anticompetitive. Thus, it is not the foreseeable result of allowing a hospital service district to form joint ventures that it will engage in anticompetitive conduct." Id. at 235; accord Lancaster Cmty. Hosp. v. Antelope Valley Hosp. Dist., 940 F.2d 397 (9th Cir. 1991), cert. denied, 502 U.S. 1094 (1992).

74. Town of Hallie v. City of Eau Claire, 471 U.S. 34, 36-37 (1985). 
eas, ${ }^{75}$ but it did not expressly authorize anticompetitive actions or antitrust violations. Likewise, in City of Columbia v. Omni Outdoor Advertising, Inc., ${ }^{76}$ the Supreme Court found it sufficiently foreseeable that a grant of power to regulate the land use process contemplated the power to control the type and placement of advertising billboards. ${ }^{77}$ In sharp contrast, all corporations are granted the power to enter into contracts, but this hardly expresses a "clear articulation" of the state's desire that they be permitted to enter into anticompetitive agreements. ${ }^{78}$

As a general rule, ambiguities in state authorizing provisions should be construed against authorization. This conclusion flows from the fact that the antitrust laws declare a clear national policy of preventing anticompetitive restraints, and that most states declare a similar policy via their own antitrust laws or regulatory provisions. As a result, state and local government regulatory policy is painted on a canvas in which federal and state policies favoring competition form a clear background. While the Parker doctrine rests on the premise that a state is free to deviate from this policy in specific situations if it chooses, such deviations should not be found absent a clear expression by the state that it desires to do so. ${ }^{79}$

75. See WIS. Stat. $\$ 66.069$ (2) (c) (1981-1982), (renumbered in part and repealed in part by 1999 Act 150, current version at $\$ 66.0813$ (3) (a) (2003)) (A city providing a public utility "may by ordinance fix the limits of such service in unincorporated areas. Such ordinance shall delineate the area within which service will be provided and the municipal utility shall have no obligation to serve beyond the area so delineated.").

Further, another Wisconsin statute provided that the state's Department of Natural Resources may require a city to interconnect with surrounding areas; however, it also provided that such an order would be void if the outlying territory refused to become annexed to the city. See WIS. STAT. \$ 144.07(1) (1981-1982) (renumbered by 1995 Act 227, current version at $\$ 283.43(2005)$ ); Town of Hallie, 471 U.S. at 41.

76. 499 U.S. 365 (1991).

77. Id. at $370-72$.

78. See the FTC's state action Task Force Report, which would inquire "whether the state has deliberately adopted a policy to displace competition in the manner at issue." Fed. Trade Comm'n, Office of Policy Planning, Report of the State action Task force 51 (2003) [hereinafter TASK ForCe RePORT]; see also The State Action Doctrine: Hearing Before the Antitrust Modernization Comm'n (2005) (statement of Maureen K. Ohlhausen, Dir., Office of Policy Planning, Fed. Trade Comm'n), available at http://www.amc.gov/commission_hearings/pdf/Ohlhausen_Statement.pdf (last visited Mar. 15, 2006).

79. When a state wishes to, its authorization can be very clear. Consider this Georgia statute:

It is declared by the General Assembly of Georgia that in the exercise of powers specifically granted to them by law, local governing authorities of cities and counties are acting pursuant to state policy ... . This chapter is intended to articulate clearly and express affirmatively the policy of the State of Georgia that in the exercise of such powers, such local governing authorities shall be immune from 
When a state grants power to an inferior entity, it ${ }^{\circ}$ presumably grants the power to do the thing contemplated, but not to do so anticompetitively. For example, an authorization to a corporation to enter into contracts is not to be construed as an authorization to enter into price fixing or other anticompetitive agreements unless the authorizing provision states so clearly.

\section{Active Supervision Requirement Reforms}

The problem with the "active supervision" requirement has not been quite as severe since the Supreme Court's decision in Ticor Title, ${ }^{80}$ establishing that active supervision requires actual government review of private conduct. ${ }^{81}$ Nevertheless, there are still problem areas. For example, there is much to be said for the FTC's suggestion that if a state regulatory agency is going to approve a particular instance of rate bureaus or other forms of regulatory price fixing, it should issue a written opinion on the merits, supported by a set of fact findings that explain its decision. ${ }^{82}$ Such reasoned elaborations serve to provide transparency to the process and help ensure that agency decisions do not reflect simple private interest capture. ${ }^{83}$ This prong of the Midcal test requires that the state both "have and exercise ultimate authority" ${ }^{4}$ so that it can be said that the resulting decision is a product of "deliberate state intervention, not simply by agreement among private parties." 85

\section{The Problem of Spillovers}

Whenever we consider the values of federalism and the respective roles of state and federal regulation, some attention must be given to

antitrust liability to the same degree and extent as enjoyed by the State of Georgia.

GA. Code ANN. § 36-65-1, -2 (2000); see McCallum v. City of Athens, 976 F.2d 649, 655 (11th Cir. 1992) (stating that "by enacting [this provision] Georgia unequivocally revealed that it contemplated that its municipalities might engage in anticompetitive conduct").

80. FTC v. Ticor Title Ins. Co., 504 U.S. 621 (1992).

81. But see William J. Martin, Comment, State Action Antitrust Immunity for Municipally Supervised Parties, 72 U. CHI. L. Rev. 1079 (2005) (arguing that the courts analyze claims of state supervision rigorously, while applying a much more lenient standard to local government supervision).

82. See TASK ForCE REPORT, supra note 78, at 55.

83. See Timothy J. Muris, Clarifying the State Action and Noerr Exemptions, 27 Harv. J.L. \& Pub. Pol'y 443, 448 (2004).

84. Patrick v. Burget, 486 U.S. 94, 101 (1988) (quoting So. Motor Carriers Rate Conference, Inc. v. United States, 417 U.S. 48, 51 (1985)); see generally 1A AREEDA \& HovenKamp, supra note 2, I 226c (3d ed.).

85. Ticor, 504 U.S. at 634-35. 
the problem of spillovers, or extraterritorial effects. It is one thing to approve an anticompetitive state regulatory scheme when the burden falls substantially on that state's own residents. But federalism does not require federal authority to permit states to export anticompetitive regulatory schemes. Under the current formulation of the state action exemption, extraterritorial impact of state regulatory schemes is not even regarded as relevant. To be sure, antitrust is not the only vehicle for addressing these problems. Anticompetitive state regulatory schemes that have too severe an impact on interstate commerce can and have been struck down under the Commerce Clause. ${ }^{86}$

The Federal Trade Commission's Report of its State Action Task Force ("Task Force Report") is quite concerned about extraterritorial spillovers of anticompetitive state regulation. ${ }^{87}$ As that document observes, the spillover problem has long been recognized in the academic literature. ${ }^{88}$ However, the Task Force Report then noted only Parker itself as a decision that involved significant spillovers. ${ }^{89}$

Under the state action doctrine in its current form, spillovers are simply irrelevant to the question of antitrust illegality. If the state has sufficiently articulated its wish to displace the antitrust laws and pri-

86. See, e.g., Granholm v. Heald, 544 U.S. 460 (2005) (ban on out-of-state wine shipments violates Commerce Clause); So. Cent. Bell Tel. Co. v. Alabama, 526 U.S. 160 (1999) (discriminatory franchise tax levied on out-of-state corporations violated commerce clause); Gen. Motors Corp. v. Tracy, 519 U.S. 278 (1997) (use tax exemption that favored in-state sellers of natural gas did not violate either commerce clause or equal protection clause); Fulton Corp. v. Faulkner, 516 U.S. 325 (1996) (striking down North Carolina tax on residents' ownership of out of state corporate shares); Associated Indus. of Mo. v. Lohman, 511 U.S. 641 (1994) (striking down tax on value of goods purchased outside the state but consumed, used, or stored inside the state); Dean Milk Co. v. City of Madison, 340 U.S. 349 (1951) (statute prohibited sale of milk as pasteurized unless processed within five miles of Madison).

87. See TASK FORCE REPORT, supra note 78 , at $40-44,56-57$.

88. Id. at 40-44 (citing Robert P. Inman \& Daniel L. Rubinfeld, Making Sense of the Antitrust State-Action Doctrine: Balancing Political Participation and Economic Efficiency in Regulatory Federalism, 75 TEx. L. Rev. 1203 (1997)); Thomas M. Jorde, Antitrust and the New State Action Doctrine: A Return to Deferential Economic Federalism, 75 CAL. L. REv. 227 (1987); David McGowan \& Mark A. Lemley, Antitrust Immunity: State Action and Federalism, Petitioning and the First Amendment, 17 Harv. J.L. \& Pub. PoL'y 293 (1994); Einer Elhauge, The Scope of Antitrust Process, 104 HaRv. L. REv. 667 (1991); John E. Lopatka, State Action and Municipal Antitrust Immunity: An Economic Approach, 53 FordHAM L. REv. 23 (1984); Frank H. Easterbrook, Antitrust and the Economics of Federalism, 26 J.L. \& Econ. 23 (1983); Hovenkamp \& Mackerron, supra note 45, at 719; William E. Kovacic, Lessons of Competition Policy Reform in Transition Economies for U.S. Antitrust Policy, 74 St. John's L. Rev. 361 (2000).

89. See TAsk Force Report, supra note 78, at 40. The TASK Force Report also noted the example given in City of Lafayette v. Louisiana Power E Light Co. that "a municipality conceivably might charge discriminatorily higher rates to such captive customers outside its jurisdiction without a cost-justified basis." 435 U.S. 389, 404 (1978). But the Report did not suggest that significant spillovers were at issue in Lafayette. 
vate conduct is adequately supervised, then it does not matter how much the regulatory program in question injures those outside the jurisdiction of the state or local government imposing the regulation. As a consequence, judicial records are not developed so as to highlight spillover effects. A coherent doctrine of spillovers and its inclusion as a state action immunity requirement will therefore require some new directions in case development.

\section{Administrative Reforms}

Inadequate factual development in the existing case law is hardly the only problem. The most serious difficulty is administrative. The "clear articulation" and "active supervision" prongs of the state action doctrine are designed to promote rapid and fairly easy disposition of antitrust challenges to state and local government. Ideally, "articulation" can be assessed by looking at a state's statutes, or perhaps legislative history, regulations, or occasionally case law. Generally these things can be judicially noticed, making the authorization requirement an ideal candidate for motions to dismiss under Rule 12(b) (6). "Active supervision" can be a little more difficult, but need not be. Often the public records provide ample evidence of supervision or the lack of such evidence. As a result, state action immunity questions are often resolved on motions to dismiss.

In contrast, measurement of "spillovers" in the context of antitrust litigation would at best be an empirically challenging exercise. First, every state and local regulation has some spillover. For example, out-of-state visitors may have to use the trash disposal, ${ }^{90}$ taxicab, ${ }^{91}$ hospital, $^{92}$ or ambulance services ${ }^{93}$ that are subject to a challenged re-

90. See, e.g., S. Disposal, Inc. v. Tex. Waste Mgmt., Inc., 161 F.3d 1259 (10th Cir. 1998); Hancock Indus. v. Schaeffer, 811 F.2d 225 (3d Cir. 1987).

91. See Charley's Taxi Radio Dispatch Corp. v. SIDA of Haw., Inc., 810 F.2d 869, 875 (9th Cir. 1987); Campbell v. City of Chi., 823 F.2d 1182 (7th Cir. 1987); Indep. Taxicab Drivers' Employees v. Greater Houston Transp. Co., 760 F.2d 607 (5th Cir. 1985), cert. denied, 474 U.S. 903 (1986); Santos v. City of Houston, 852 F. Supp. 601 (S.D. Tex. 1994); Woolen v. Surtran Taxicabs, Inc., 461 F. Supp. 1025 (N.D. Tex. 1978). Most of these involved exclusive licenses for things such as airport pickup, often from large international airports such as Dallas-Ft. Worth (Woolen), Houston (Independent Taxicab Drivers), or O'Hare (Campbell). None of the decisions mentioned interstate spillover effects.

92. Jackson, Tenn. Hosp. Co. v. W. Tenn. Healthcare, Inc., 414 F.3d 608, 611 (6th Cir. 2005); Surgical Care Ctr. of Hammond v. Hosp. Serv. Dist., 171 F.3d 231 (5th Cir.), cert. denied, 528 U.S. 964 (1999); Martin v. Mem'l Hosp. at Gulfport, 86 F.3d 1391 (5th Cir. 1996).

93. A-1 Ambulance Serv., Inc. v. County of Monterey, 90 F.3d 333 (9th Cir. 1996); Gold Cross Ambulance \& Transfer v. City of Kan. City, 705 F.2d 1005 (8th Cir. 1983), cert. denied, 471 U.S. 1003 (1985). 
straint. The resale price maintenance scheme at issue in Midcal almost certainly affected out-of-state wine purchasers. ${ }^{94}$ But unless we want to jettison the state action exemption altogether, these spillovers must be regarded as de minimis, or as not sufficiently substantial to invoke any exception to the immunity.

Beyond that, we certainly cannot expect litigants to conduct a cost-benefit analysis tailored after the Kaldor-Hicks model of economic efficiency, asking whether the harmful impact on out-of-state interests was larger than the benefits conferred on in-state residents. Doing so would move the state action immunity from one of relatively simple disposition on motions to dismiss or early summary judgment into a litigation nightmare involving multiple experts and costly empirical studies. It must be borne in mind that often these disputes are relatively small in the world of antitrust cases, involving such things as a single physician's challenge to the policies of a public hospital, or a small trash removal firm's or taxicab operator's challenge to an exclusive franchise. Further, public defendants such as municipalities lack the resources for costly litigation.

To be sure, one can imagine egregious situations in which the impact of state regulation falls almost entirely on out-of-state interests, but then it seems the dormant Commerce Clause would be sufficient to handle the problem. ${ }^{95}$

It is largely for this reason that the ANTITRUST LAw treatise has played down the spillover problem, even though I was one of the authors cited in the Task Force Report as stating the spillover concern. ${ }^{96}$ It is a concern, but the most fundamental piece of cost-benefit analysis is an assessment of whether the benefits of taking extraterritorial spillovers into account will justify the very considerable increase in costs likely to affect most state action cases.

The authors of the Task Force Report appear to be aware of this, although they did not explicitly articulate the concern. The Task Force Report argues that "overwhelming" state spillovers be taken into account in deciding the immunity question. ${ }^{97}$ The limitation to overwhelming is undoubtedly intended to address the fact finding problem, but even so, a broad factual inquiry will be required. The authors then add in a footnote:

94. Cal. Retail Liquor Dealers Ass'n v. Midcal Aluminum, Inc., 445 U.S. 97 (1980).

95. See cases cited supra notes 91-94.

96. See TASK FORCE REPORT, supra note 78, at 43 n.186 (citing Hovenkamp \& Mackerron, supra note 45 ).

97. Id. at 56. 
When the degree [sic] of spillover is more marginal, and difficult to measure, prudence and a desire for legal rules with ex ante predictability counsel against giving significant weight to interstate spillovers. But where the benefits of a given anticompetitive restriction accrue overwhelmingly to residents of the state implementing the restriction, and the harms fall overwhelmingly on residents of other states, then the considerations behind both the Interstate Commerce Clause and the federal antitrust laws are at their height, and the case for judicial recognition of those spillovers is at its strongest. 98

Still, one wonders whether there will be restraints that meet this test for antitrust purposes, but would not be excluded in any event by the dormant Commerce Clause. ${ }^{99}$

\section{Need for Sensitivity to Substantive Antitrust Policy Issues}

Finally, antitrust tribunals need to be somewhat more sensitive to substantive issues of antitrust policy in deciding questions that implicate the state action immunity. Too many cases have required lengthy appellate litigation, sometimes even to the Supreme Court, when the case could have been disposed of far more readily on antitrust grounds. The FTC has somewhat ambiguously suggested a "tiered" approach to the state action immunity, with a clearer state articulation of purpose to displace the antitrust laws required as the restraint becomes more anticompetitive. ${ }^{100}$ While one can appreciate the underlying concern, this approach overly complicates an already complex doctrine. It would be far better to require that articulation be clear in all cases, under a plain statement rule. When concerns for competition seem relatively modest, rather than watering down the articula-

98. Id. at 57 n.242.

99. One possibility is municipal restraints where the impact of the restraint falls outside of the municipality but within the state. In that case, however, the issue is probably best left to state law.

100. See Delacourt \& Zywicki, supra note 38, at 1089-90 (referring to the TASK FORCE REPORT, supra note 78, at 12). Delacourt \& Zywicki suggest:

Pursuant to such a tiered approach, the level of clear articulation required would increase or decrease, depending on the nature of the anticompetitive conduct at issue. This approach reflects that fact that, the more serious the nature of the anticompetitive conduct, the more likely it is to restrain trade. Thus, it is logical to assume that the alleged beneficiary of a restraint will be more likely to engage in more serious anticompetitive conduct as such conduct is also more likely to be successful. Increasing the level of clear articulation required to match the seriousness of the alleged anticompetitive conduct should therefore create at least a rough link between the defendant's incentives and a grant of state action protection, with the result that the "clear articulation" requirement will be most rigorous where the defendant is most likely to engage in anticompetitive conduct.

Id. at 1089. 
tion requirement, litigants and courts would do better to go straight to the merits. The previously mentioned Boulder decision, which was litigated all the way to the Supreme Court, provides a good example. Uncertain about the best course for future development of its cable television system, the City of Boulder enacted a moratorium on further expansion of its incumbent cable television provider while it considered whether such expansion was preferable to new entry by other providers. The complaint should have been dismissed on the pleadings. First, the City of Boulder was not a participant in the cable television market at all. Second, the plaintiff was claiming an antitrust right to expand its monopoly franchise rather than permitting the City to inaugurate competition. ${ }^{101}$

The state action immunity is essential in situations where state regulation endorses collusion or similar practices that are almost certainly antitrust violations when committed in the private sector. It is completely unnecessary when a state or local government regulates in a way that never gives rise to an antitrust cause of action to begin with. The tougher cases are a relatively small number in the middle, which involve arguable rule of reason violations but also a colorable case for state authorization and active supervision. With respect to these, I do not believe that a more lenient test for immunity is the right approach; the state either declares an intention to displace the antitrust laws or it does not. In most such cases, an examination of the antitrust merits would be a much quicker road to resolution.

\section{Conclusion}

Federal antitrust policy has always been delimited by concerns for federalism. While the role of the states in regulating their own economies is not as significant today as it was when the Sherman Act was passed, that is no reason for jettisoning our federal system of economic regulation, provided that preserving it is defensible on policy grounds and not too costly. When a state regulates well, appropriately limiting the range of private entrepreneurial discretion, then federal antitrust must ordinarily stand aside, even though the federal decision maker thinks that the state regulatory regime in question is poorly designed or inefficient. However, concerns for federalism do not re-

101. The plaintiff also alleged a conspiracy between the City and the cable company that wanted to enter the market to substitute the latter for the former. See 2 Areeda \& HovenKamp, supra note 2, I $348 \mathrm{e}$ (2d ed.). However, no competition is diminished when one monopoly franchise is substituted for another one, and such plaintiffs ordinarily lack standing. 2 Id. 
quire the federal antitrust tribunal simply to cave in to purely private business discretion.

To that end, the McCarran-Ferguson insurance immunity is long overdue for repeal. That statute does virtually no good and creates an immunity whose social cost in the form of increased collusion is undoubtedly very high. By contrast, the Parker state action doctrine is salvageable with much more modest fixes that leave its basic structural requirements intact. 
